\title{
Posouzení návrhu výstavby výrobních hal
}

\author{
Pavel Vránek ${ }^{1}$, Ilona Kačerová ${ }^{1}$, Filip Rybnikár ${ }^{1}$ \\ 1 Západočeská univerzita v PIzni, Fakulta strojní, Katedra průmyslového inženýrství a \\ managementu \\ Univerzitní 2732/8, 30614 Plzeň, Česká republika \\ ikacerov@kpv.zcu.cz \\ rybnikar@kpv.zcu.cz \\ vranek@kpv.zcu.cz
}

\begin{abstract}
Anotace: Článek se zabývá posouzením a pripomínkováním návrhu výstavby dvou nových výrobně skladových hal, které budou navázány na současnou budovu o rozloze $2500 \mathrm{~m}^{2}$. $V$ rámci posouzení byly tvořeny kapacitní propočty, které ověřovaly personální obsazení, prostorovou náročnost, ale také počty strojů. Cílem práce bylo nalézt úzká místa návrhu, nadefinovat připomínky $\mathrm{k}$ návrhu a současně na připomínky nalézt vhodná nápravná opatření, která povedou k optimální variantě budoucí haly.
\end{abstract}

\section{1 Úvod}

Práce je zaměřena na posouzení a prípomínkování návrhu výstavby dvou nových hal výrobní společnosti s administrativní vestavbou, které mají být $\checkmark$ budoucnu napojeny na současnou halu. $\mathrm{V}$ rámci studie byl proveden výpočet kapacit (personálních, prostorových, strojních), dále byl proveden audit funkčnosti jednotlivých prvků a obslužnosti hal. Konkrétně se jedná o následující:

- kapacitní propočty,

○ personální,

○ prostorové (výrobní plochy, skladové plochy, kanceláře, šatny, ...),

o strojní,

- definování připomínek k výstavbě a funkčnosti komplexu hal,

- návrh nápravných opatření v návaznosti na připomínky,

- závěrečné zhodnocení.

Hlavní pozornost byla zaměřena na funkčnost návrhu, obslužnost hal s ohledem na nové prostorové uspořádání, typ výroby, použité manipulační a skladové techniky.

Celkové směřování činností, $v$ rámci řešení projektu, bylo nastaveno pro zlepšení, zefektivnění nové výstavby a přehlednější orientaci $k$ řízení materiálového toku. 


\section{Využité metody průmyslového inženýrství}

$\checkmark$ rámci studie byly použity standardní metody a techniky průmyslového inženýrství. Základem této studie byly kapacitní propočty založené na odborné literatuře. Dále byly použity metody jako Sankeyův diagram, materiálové toky, ID diagram apod. V rámci studie byl využit software od společnosti Plavis $\mathrm{GmbH}$ visTABLE pro 2D a 3D vizualizaci. [1]

\section{Navržené řešení}

Před zahájením řešení studie bylo nutné seznámení $s$ prověřovaným výrobním systémem. Toto seznámení zahrnovalo setkání se zástupci společnosti a také návštěva výrobní haly. Základní charakteristika výroby byla definována na jednání a návštěvě společnosti zadavatele.

Proces práce na studii začal analýzou výkresové dokumentace, a to včetně okolí společnosti $v$ souvislosti $s$ dopravní obslužností společnosti a prristupností výrobních hal. Po analýze situačního výkresu bylo přistoupeno $\mathrm{k}$ analýze jednotlivých hal, kde byly postupně analyzovány jednotlivé výkresy hal. $V$ rámci analýzy bylo provedeno detailní zaměření na různé situace, prostupy mezi halami, výrobními a skladovými prostory, správními prostory atd.

Následně bylo prisstoupeno $\mathrm{k}$ analýze materiálových a personálních toků jednotlivých hal, včetně vstupního materiálu a výstupních hotových výrobků. Byly analyzovány materiálové toky týkající se hlavních skupin výrobků. Z každé skupiny bylo definováno 10 klíčových zástupců s nejvyšším ročním objemem výroby. Tyto materiálové toky byly zaznamenány ve výkresové dokumentaci, která byla vytvořena v pozdějších fázích studie.

Analýza také zahrnovala výpočty kapacit. Kapacitní výpočty byly nejprve zaměřeny na současný stav, díky čemuž byla ověřena funkčnost a přesnost odborného prístupu porovnáním výsledků se současným stavem. $V$ rámci srovnání bylo zjištěno, že rozdíly $v$ jednotlivých hodnotách jsou minimální, a proto je možné tuto metodiku použít ke zpracování budoucího stavu. Byly stanoveny dva milníky a to rok 2025 a 2030 . Výpočty kapacit zahrnovaly roční časové fondy pracovníků, efektivní časové fondy strojů a pracovišt', $s$ prìhlédnutím $\mathrm{k}$ efektivitě strojů podle dostupného OEE jednotlivých strojů. Dále byly provedeny výpočty personálních kapacit, aby se stanovil počet výrobních pracovníků, administrativních pracovníků, technických a ekonomických pracovníků a managementu. Výpočty kapacit také poskytovaly informace o minimálním počtu strojů a pracovišt' pro zajištění budoucích objemů výroby. Součástí kapacitních výpočtů byl také prostorový požadavek, který ověřil potřebu výstavby nových výrobních zařízení.

Po stanovení kapacitních výpočtů byl vytvořen návrh prostorového uspořádání pomocí softwaru visTable od Plavis $\mathrm{GmbH}$. 
Na základě dat $z$ výroby byl vytvořen model hal, který byl podroben analýze, určení jednotlivých oblastí současného stavu za účelem stanovení procenta výrobních, skladovacích a administrativních ploch. 2D model byl podpořen 3D vizualizací pro zobrazení aktuálního stavu a nových konstrukcí. 3D vizualizační model sloužil jako vstup pro převod modelu do virtuální reality. [1][2][4]

K prohlédnutí pracoviště ve virtuální realitě za využití brýlí Oculus Quest bylo převedeno nejenom současné prostorové uspořádání, ale také budoucí výrobní hala.

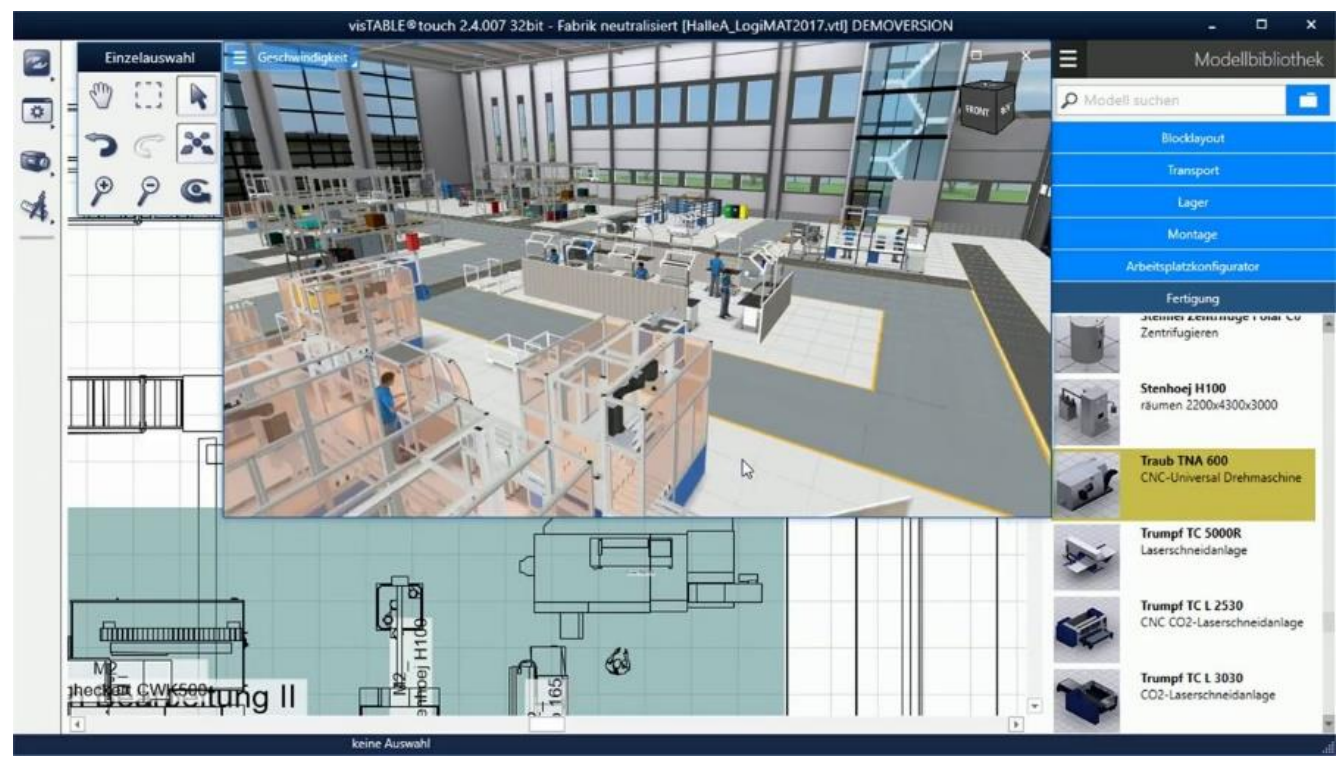

Obrázek 1 - Ukázka vizualizace [vlastní]

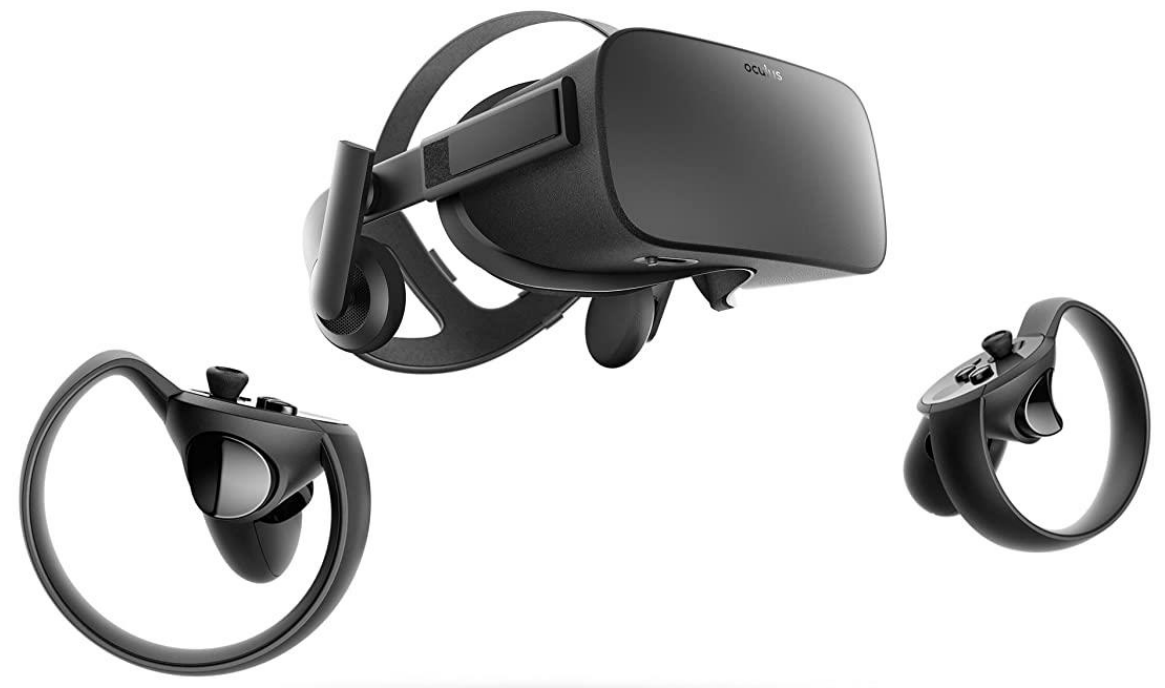

Obrázek 2 - Ukázka použitých brýlí pro virtuální realitu 


\subsection{Analýza současné situace}

Počáteční analýza byla zaměřena na analýzu situačního výkresu celého generelu. Výkres byl analyzován z hlediska bezprostředního okolí společnosti, dopravní dostupnosti a dopravních služeb společnosti. Dále byly demontovány $i$ jednotlivé haly $v$ rámci celého generelu. Během analýzy byly definovány připomínky k stavu budoucího parkoviště a hlavní silnice kolem celé společnosti.

Poté byla analýza přesunuta do interiéru výrobních hal, kde byl řešen hlavní logistický koridor, včetně rozšíření nebo přidání průchodů. Analýze byly také podrobeny administrativní prostory.

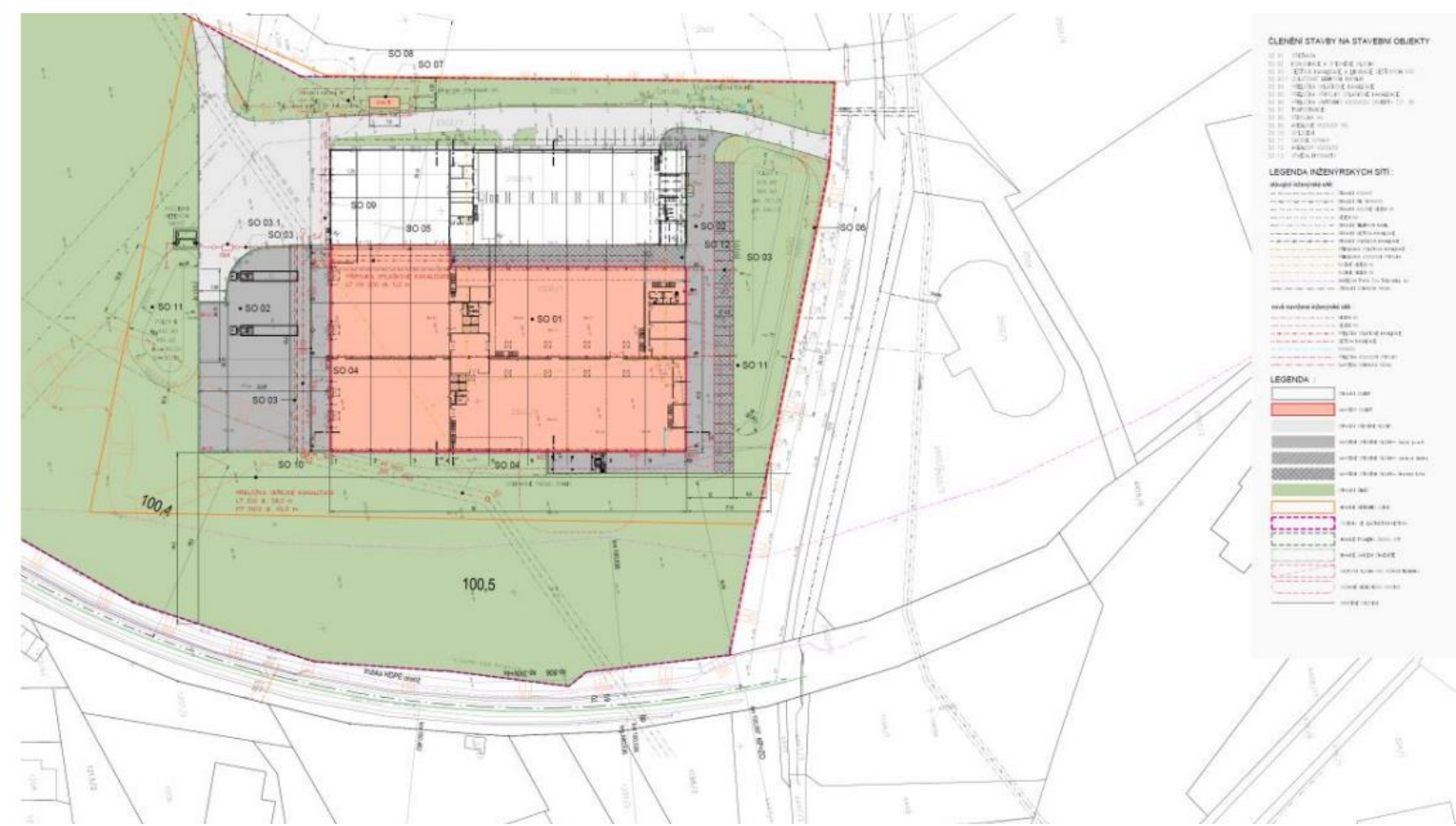

Obrázek 3 - Koordinační výkres [zdroj společnost]

\subsection{Analýza materiálových toků}

Podle výpočtů bylo zjištěno, že přibližně $40 \%$ výrobní plochy jsou výrobní prostory. Prostor je méně využíván, je to kvưli vyššímu počtu strojů na malé ploše. Při navrhování prostorového uspořádání a materiálových tokủ bylo vycházeno z budoucího plánu výroby. Návrh nového uspořádání by pak měl respektovat tento výrobní plán i strukturu výrobního programu. Ve skutečnosti je však velmi obtížné optimalizovat rozvržení tak, aby vyhovovalo všem typům produktů.

Pro následující analýzu bylo nutné zpracovat informace týkající se pohybů ve výrobě, vč. rozměrư přepravovaného materiálu a jeho množství. Z diskusí a dokumentů byly získány zejména tyto informace:

- zahájení pracoviště,

- pracoviště terminálu,

- rozměry balení, 
- objem výroby.

Tato data byla použita pro stanovení materiálových toků. Tabulka materiálových toků byla součástí výstupů a promítla se do jejich vizualizace. $\mathrm{Na}$ základě budoucích objemů výroby a skutečných materiálových toků byl vytvořen model současného stavu výroby, který ukazuje na 2D rozvržení materiálových toků společnosti pro základní skupiny produktů. [2]

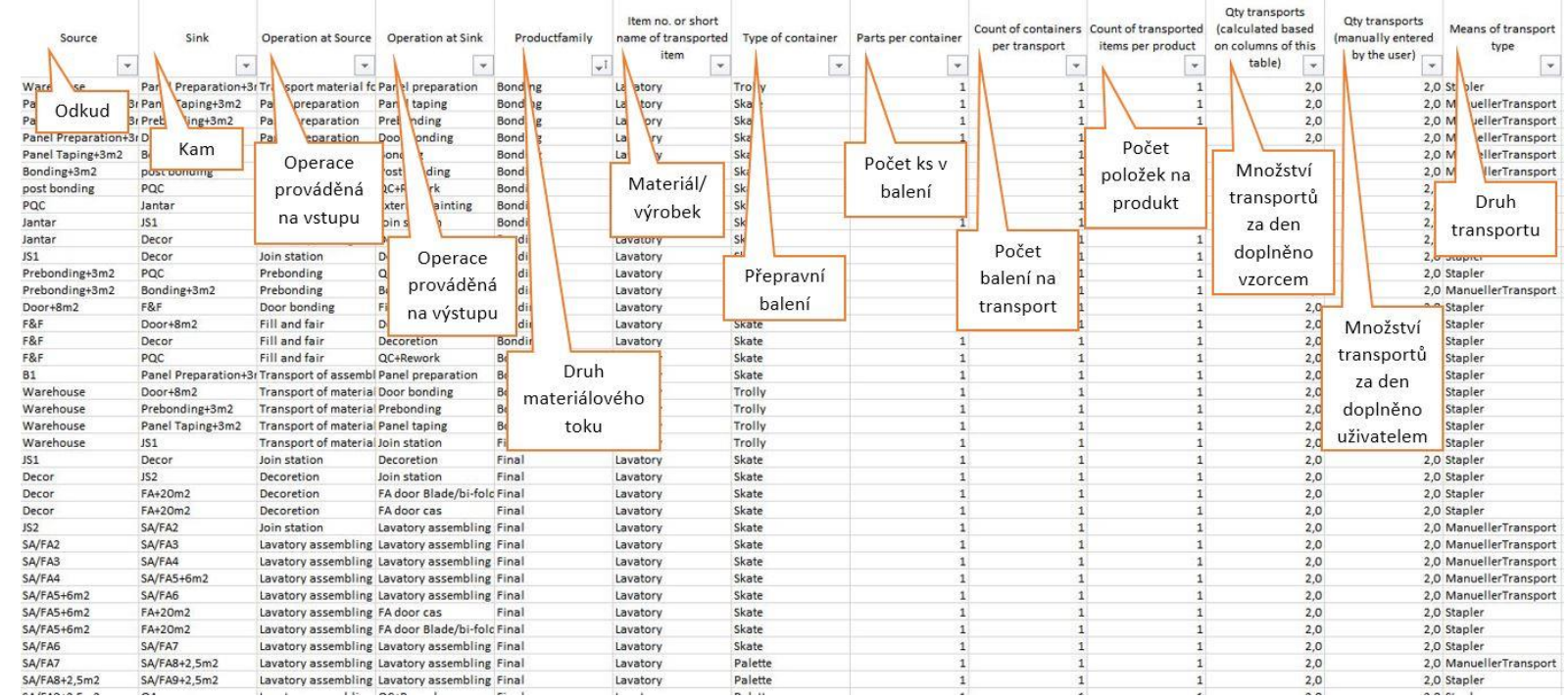

Obrázek 4 - Ukázka materiálových toků

\subsection{Kapacitní propočty}

Na základě dostupných údajů byly vypočteny kapacity strojů a pracovišt'. Vstupními údaji byly výpočty časových prostředků pracovníků, strojů a pracovišt'. Výstupem kapacitních výpočtů nejsou jen potřeby pracovníků, administrativních pracovníků a manažerů, ale také potřeby strojů, pracovišt' a nároky na výrobní, administrativní a společenské prostory. Na základě změn v objemu výroby byly kalkulace kapacit stanoveny také pro horizont 5 a 10 let. Výpočty kapacity potvrdily potřebu vybudovat další výrobní halu. $V$ prípadě přesnějších údajů je možné upravit výpočty kapacity tak, aby se stanovily konkrétní potřeby. Příklad výpočtů kapacit je uveden na obrázku níže (viz dodatek: Výpočty kapacity). Výpočty kapacity zahrnují počet pracovišt' a počet strojů, následující obrázek ukazuje príklad počtu strojů [4] [5].

\section{Tabulka 1 - Výpočet kapacit}

\begin{tabular}{|c|c|c|c|c|c|c|c|c|}
\hline \multicolumn{9}{|c|}{ Polet strejs (anokrowhleno nahoru) } \\
\hline & Shuteline polty strojs & & s & 2 & 2 & & 4 & 21 \\
\hline & \multicolumn{2}{|c|}{ Primetrins hodineved produbce stroje } & 6152 & 519 & 5288 & & 319 & 2145 \\
\hline & \multicolumn{2}{|c|}{ Polet hodin nu wirobu divily } & 4214 & 1951 & 4716 & RChirN Nusoul & 6443 & 12060 \\
\hline \multicolumn{3}{|c|}{$t_{n}=$ Cas pligrany o zakonden $(5-20)$} & 20 & & & & 2 & 9 \\
\hline \multirow{2}{*}{ a. } & & & & & & & & \\
\hline & velilkost wirobni dovky & Q/o & 25926333.8 & 1012504 & 24940000 & sctibai nuLOU] & 2055338.00 & 2586782450 \\
\hline \multicolumn{3}{|c|}{ d, - velikost wirobni dovky ipo z zagkrouhis nahoru } & 25926334 & 1012504 & 24940000 & ECLITNI NuSOU] & 2055398 & 2586725 \\
\hline \multicolumn{2}{|c|}{ Q- polet kusú za sledevant obdobi } & dob: & 1037053355 & 4050016 & 99760000 & & 8221352 & 103471293 \\
\hline o- & polet divek & & 4 & 4 & 4 & 0 & 4 & 4 \\
\hline \multicolumn{3}{|c|}{ 0. potet divek (po zaokirouhieni nahorv) } & 4 & 4 & 4 & o & 4 & 4 \\
\hline \multicolumn{3}{|c|}{$\mathrm{T}_{4}-$ las cellowi (oolet hodin nu wirobu rolinho objemul) } & 16457.17 & 7803.50 & 2 2anes 36 & achirni nutoul & 2577226 & 4123857 \\
\hline $\mathbf{P}_{\mathbf{2}}-\mathbf{B}$ & polet strejü & & 436262274 & 1.7670967 & 4272046087 & Q & 5.85610354 & 11.65177978 \\
\hline
\end{tabular}


Tabulka 2 - Výpočet kapacit

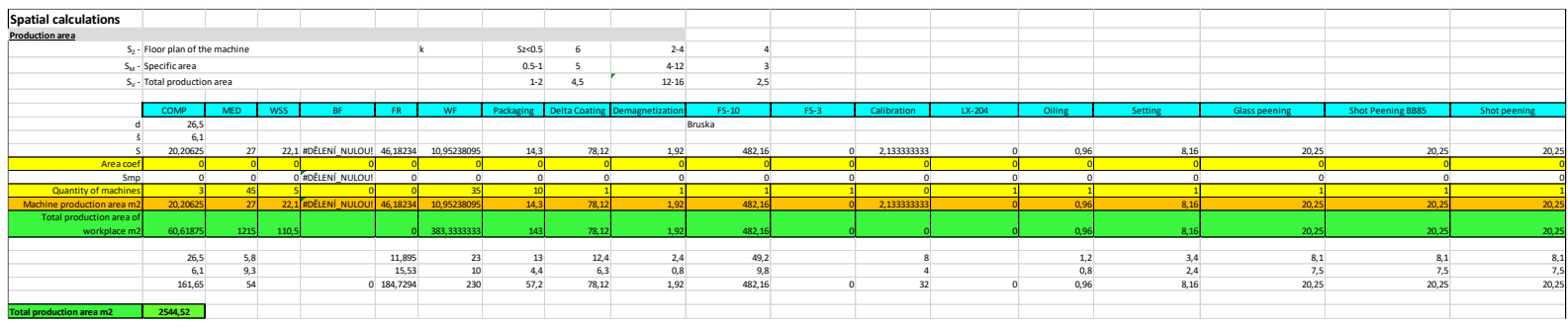

Výpočty kapacit rovněž zahrnovaly výpočty počtu pracovníků ve výrobě, pomocných pracovníků ve výrobě nebo administrativních pracovníků a managementu. Následující obrázek ukazuje výpočet kapacity výrobních pracovníků.

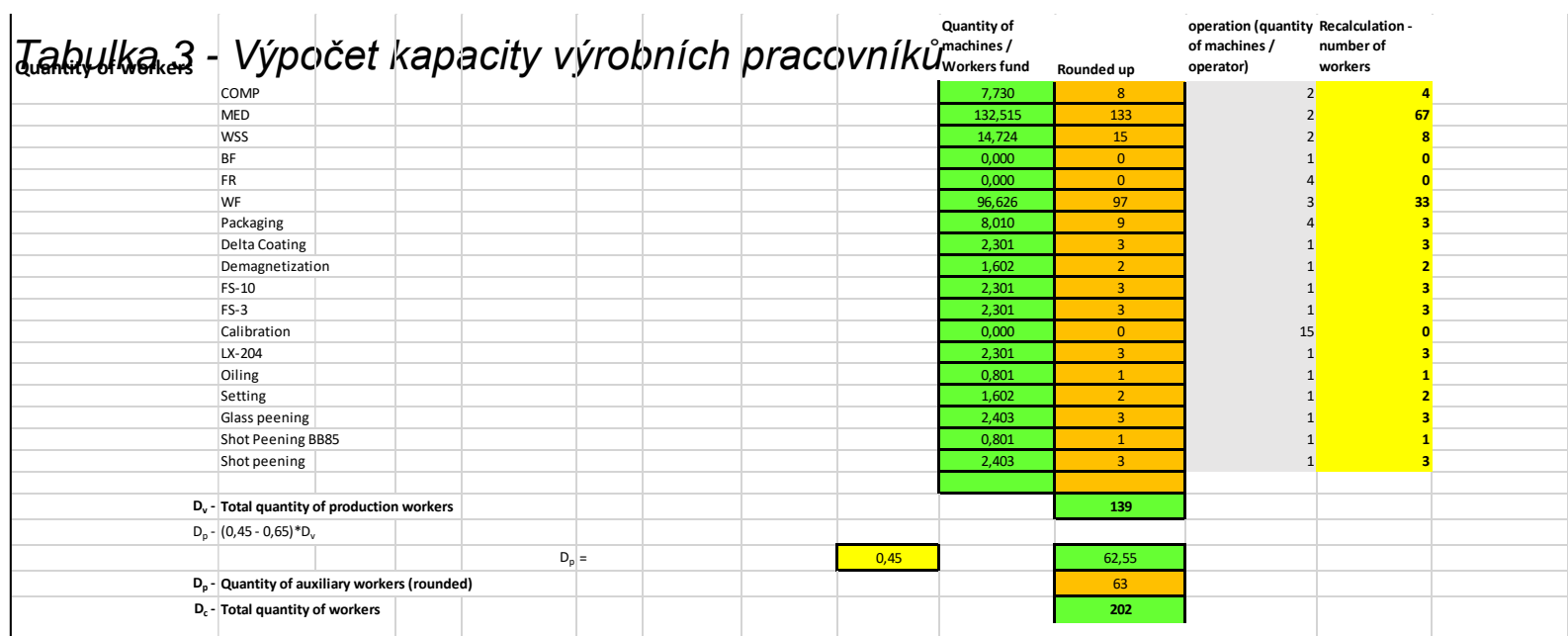

Výpočty byly také použity pro výpočet požadovaných ploch pro aktuální stav výrobních hal. Následuje srovnání výpočtů prostorové kapacity současného stavu a horizontu 5, respektive 10 let.

\begin{tabular}{|l|r|l|}
\hline \multicolumn{4}{|c|}{2020} \\
\hline Total production area & $\mathbf{2 1 3 4 , 9 5}$ & $\mathrm{m} 2$ \\
\hline Total warehouse area & 600 & $\mathrm{~m} 2$ \\
\hline Total area of company & 2734,95 & $\mathrm{~m} 2$ \\
\hline \multicolumn{3}{|c|}{2025} \\
\hline Total production area & 3038,61 & $\mathrm{~m} 2$ \\
\hline Total warehouse area & 600 & $\mathrm{~m} 2$ \\
\hline Total area of company & 3638,61 & $\mathrm{~m} 2$ \\
\hline \multicolumn{3}{|c|}{20} \\
\hline Total production area & 3894,43 & $\mathrm{~m} 2$ \\
\hline Total warehouse area & 600 & $\mathrm{~m} 2$ \\
\hline Total area of company & 4494,43 & $\mathrm{~m} 2$ \\
\hline
\end{tabular}

Obrázek 5 - Výpočet prostorové kapacity

Výpočty kapacity podle výše uvedeného obrázku ukazují, že výstavba nových výrobních zařízení je oprávněná a je vhodné rozšírit výrobu. 


\section{Závěr}

Tato studie byla zaměřena na analýzu současného návrhu výstavby nových výrobních prostor $\mathrm{s}$ ohledem na prostorové uspořádání výrobních, skladovacích a administrativních prostor. Součástí studie bylo analyzovat výkresovou dokumentaci, analýzu materiálových toků, výpočty kapacity podle současných a budoucích objemů, které byly vytvořeny, za účelem návrhu zlepšení výkresové dokumentace, nalezení nedostatků $v$ navrhovaném územním uspořádání a vytvoření prípomínek $\mathrm{k}$ tomuto návrhu. Studie byla rozdělena do několika částí.

První částí byla podrobná analýza výkresové dokumentace výstavby nových výrobních prostor a změn stávajících prostor. $S$ využitím dostupných údajů zadavatele byly vytvořeny návrhy a připomínky $\mathrm{k}$ návrhu, jejichž cílem bylo zlepšit a zefektivnit výstavbu nových výrobních zařízení o bezpečnosti práce. $\checkmark$ další části práce bylo analyzováno portfolio produktů napříč všemi skupinami produktů a jejich zástupci. Podle této analýzy byly vytvořeny materiálové toky podle současného stavu $v$ roce 2020 a také pro budoucí stavy podle budoucích objemů výroby pro rok 2025 a 2030. V následující části byly provedeny kapacitní výpočty současného stavu, které přibližně odpovídají aktuální situaci ve společnosti. Podle budoucích objemů výroby byly kalkulace kapacity provedeny pro roky 2025 a 2030, kde bylo potvrzeno, že výstavba nových výrobních zařízení je odůvodněna potřebou zvýšit výrobu. Výpočty kapacit byly zaměřeny na potřebu výrobních a pomocných pracovníků, personální zabezpečení administrativních pracovníků, THP a management, počet strojů a pracovišt', jakož i na prostorové požadavky současného stavu v roce 2020 a budoucí podmínky v letech 2025 a 2030 . V poslední části studie $2 \mathrm{D}$ a $3 \mathrm{D}$ modely výroby byly vytvořeny haly pro vizualizaci nových výrobních prostor včetně možných modifikací a také pro vizualizaci materiálových toků. Současně byl vytvořen 3D model pro propojení analyzovaných výrobních hal s virtuální realitou.

\section{Poděkování}

Tento článek byl vytvořen za podpory interního grantu Západočeské univerzity číslo projektu je SGS-2018-031 s názvem Optimalizace parametrů udržitelného výrobního systému.

\section{Použitá literatura}

[1] MILLER, A., BUREŠ, M., ŠRAJER, V., PEŠL, J. Projektování výrobní základny - teoretická ćást. 1. vyd. Plzeň: SmartMotion s.r.o., 2013. ISBN 978-80-87539-30-9.

[2] Digital Factory. Tvorba prostorového uspořádání. [online]. Plzeň, 2011 [cit. 15.11.2019]. Dostupné z: http://digipod.zcu.cz/index.php/cs/oblastinasazeni/tvorba-prostorovehousporadani 
[3] MILLER, A., BUREŠ, M., KURKIN, O., PEŠL, J. Projektování výrobní základny - praktická část. 1. vyd. Plzeň: SmartMotion s.r.o., 2013, ISBN: 978-80-87539-31-6

[4] ZOUBEK, M. Prostorové uspořádání pro nový výrobní program. Diplomová práce, [online]. Plzeň, 2016 [cit. 20.8.2020], Dostupné z: https://dspace5.zcu.cz/bitstream/11025/25207/1/Diplomova prace $\mathrm{Pr}$ ostorove usporadani Michal Zoubek.pdf

[5] RYBNIKÁR, F., KLEINOVÁ, J. Změna uspořádání pracoviště za účelem zvýšení objemu výroby. Plzeň, 2019, DOI: 10.24132/PI.2019.08948.136-144 